Jurnal Kesehatan Reproduksi

Vol. 7 No. 3 - Desember 2020

\title{
Determinan Kejadian Berat Bayi Lahir Rendah
}

\author{
Iva Inpresari ${ }^{1}$, Wiwik Eko Pertiwi ${ }^{2 *}$, \\ 1,2 Program Studi Kesehatan Masyarakat, Universitas Faletehan Serang, Banten, Indonesia \\ Korespondesi: wiek.ep@gmail.com
}

Submisi: 28 Oktober 2019; Revisi: 15 Oktober 2020; Penerimaan: 10 November 2020

\begin{abstract}
Background: Riskesdas (2018), shows that the proportion of LBW in Indonesia is $6.2 \%$ and has not yet reached the 2019 National target (6.9\%). The number of LBW in Serang District Health Office (DHO) during 2018 reached 662 cases, and babies with LBW ranks first among the causes of infant death in Serang District, as many 84 cases (35\%) of babies died due to LBW. Jawilan Public Health Centre ranks first (7\%) and then Petir Public Health Centre as many $6 \%$ in the LBW incidence rate in Serang District.

Objective: This study aims to determine the factors associated with the incidence of Low Birth Weight (LBW).

Method: This study uses a case control design. The study was conducted in March to June 2019 with a sample of 142 people consisting of 71 case samples and 71 control samples. Case samples in this study were mothers who gave birth to babies with birth weights less than $2500 \mathrm{mg}(2.5 \mathrm{~kg})$ and control samples were mothers who gave birth to babies of normal weight.

Results and Discussion: The results showed that $22.5 \%$ of ANC frequencies were not good, $33.8 \%$ of upper arm circumference/LILA were not good, $41.5 \%$ of pregnancy distances were at risk and $18.3 \%$ were preeclampsia. The results showed that there was a significant relationship between ANC frequency and size of LILA with LBW ( $p v=0.003, p v=0.008)$, there was no relationship between pregnancy distance, preeclampsia with LBW ( $p v=0.089$, $\mathrm{pv}=0.129$ ).

Conclusion: there was no correlation between pregnancy distance, preeclampsia with LBW.
\end{abstract}

Key word: ANC frequency; Low Birth Weight; Size of LILA

\section{ABSTRAK}

Latar Belakang: Riskesdas (2018), menunjukkan bahwa proporsi BBLR di Indonesia sebesar 6,2 \% dan belum mencapai target Sirkesnas tahun 2019 (6,9\%). Jumlah BBLR di Dinas Kesehatan Kabupaten Serang selama tahun 2018 mencapai 662 kasus, dan bayi dengan BBLR menempati urutan pertama dari penyebab kematian bayi di Kabupaten Serang yaitu 84 kasus (35\%) bayi meninggal karena BBLR. Puskesmas Jawilan menempati urutan pertama (7\%) dan puskesmas Petir menempati urutan kedua (6\%) dalam angka kejadian BBLR di Kabupaten Serang.

Tujuan: Penelitian ini bertujuan untuk mengetahui faktor-faktor yang berhubungan dengan kejadian Berat Badan Lahir Rendah (BBLR).

Metode: Penelitian ini menggunakan desain kasus kontrol. Penelitian dilakukan pada bulan Maret sampai Juni 2019 dengan sampel sebanyak 142 orang yang terdiri dari sampel kasus sebanyak 71 orang dan sampel kontrol sebanyak 71 orang. Sampel kasus pada penelitian ini adalah ibu-ibu yang melahirkan bayi dengan berat lahir kurang dari $2500 \mathrm{mg}(2,5 \mathrm{Kg})$ dan sampel kontrol yaitu ibu yang melahirkan bayi dengan berat badan normal.

Hasil dan Pembahasan: Hasil penelitian menunjukkan 22,5\% ANC kurang dari 4 kali 33,8\% ukuran LILA responden kurang dari 23,5 cm), 41,5\% jarak kehamilan beresiko dan 18,3\% preeklamsia. Hasil uji analisis menunjukkan terdapat hubungan yang signifikan antara frekuensi ANC dan ukuran LILA dengan BBLR, $p=0,003$ dan $p=0,008$ secara berurutan. Tidak terdapat hubungan antara jarak kehamilan dan preeklampsi dengan $B B L R$ ( $p=0,089$ dan $\mathrm{p}=0,129$ secara berurutan).

Kesimpulan: Variabel yang berhubungan dengan kejadian BBLR adalah frekuensi ANC dan ukuran LILA.

Kata kunci: frekuensi ANC; ukuran LILA; BBLR 


\section{PENDAHULUAN}

Bayi merupakan generasi penerus kehidupan sebuah negara, karena itu kualitas terbaik dari seorang bayi dalam melanjutkan pembangunan sangat penting. Bayi dikatakan berkualitas jika status kesehatannya baik, hal ini ditandai dengan menurunnya permasalahan kesehatan yang terjadi pada bayi. Salah satu indikator yang digunakan untuk mengukur keberhasilan pembangunan kesehatan pada bayi adalah Angka Kematian Bayi (AKB). Survei Demografi dan Kesehatan Indonesia (SDKI) 2017, menunjukkan AKB lebih rendah dibandingkan dengan hasil SDKI 2012, tahun 2012 angka kematian bayi tercatat mencapai 29 per 1.000 kelahiran hidup dan tahun 2017 angka kematian bayi menjadi 24 per 1.000 kelahiran hidup ${ }^{1}$.

Angka Kematian Bayi (AKB) di Indonesia masih tinggi, tahun 2017 angka kematian neonatal 15/1.000 $\mathrm{KH}$ yang menempatkan Indonesia berada dalam sepuluh negara dengan angka kematian neonatal tertinggi di dunia. Salah satu faktor penyebab terjadinya kematian pada bayi adalah Bayi Berat Lahir Rendah (BBLR). Jumlah Bayi Berat Lahir Rendah (BBLR) di Indonesia masih cukup tinggi. Data WHO mencatat Indonesia berada di peringkat sembilan dunia dengan persentase BBLR lebih dari 15,5\% dari kelahiran bayi setiap tahunnya. Indonesia masuk 10 besar dunia kasus BBLR terbanyak, sementara kasus tertinggi di kawasan Asia Selatan seperti India dan Bangladesh. Berdasarkan hasil Riskesdas tahun 2018, menunjukkan bahwa proporsi BBLR di Indonesia sebesar 6,2\%. Angka ini menunjukkan bahwa capaian proporsi BBLR di Indonesia telah mencapai Target RPJM tahun 2019 sebesar 8\%, sedangkan berdasarkan Survei Kesehatan Nasional (Sirkesnas) tahun 2016 ditargetkan proporsi BBLR sebesar 6,9\% ${ }^{2}$. Perkembangan data jumlah BBLR berdasarkan hasil Riskesdas dari tahun 2007 sampai tahun 2018 menunjukkan peningkatan. BBLR merupakan indikator Kementerian Kesehatan dalam peningkatan status kesehatan masyarakat yaitu menurunnya persentase BBLR dari $10,2 \%$ menjadi $8 \%^{3}$.

BBLR di Provinsi Banten menempati urutan 9 besar dari 34 Provinsi yang ada di Indonesia². Jumlah BBLR di Dinas Kesehatan Kabupaten Serang periode Januari sampai Desember 2018 mencapai 662 kasus, dan bayi dengan BBLR tersebut menempati urutan pertama dari penyebab kematian bayi di Kabupaten Serang yaitu 84 kasus dari 240 bayi yang meninggal (35\%). Berdasarkan data tersebut dari 662 kasus BBLR, puskesmas Jawilan menempati urutan pertama yaitu 47 kasus (7\%) dan puskesmas Petir menempati urutan kedua yaitu 40 kasus (6\%). Berdasarkan data yang diperoleh dari puskesmas Jawilan pada tahun 2018 dari jumlah 1.216 kelahiran 47 (4\%) kasus diantaranya adalah BBLR dan dari 47 kasus kelahiran BBLR terdapat 5 yang meninggal (11\%) (Dinkes Kab. Serang, 2019). Sedangkan data yang diperoleh dari puskesmas Petir, pada tahun 2018 dari 1.247 kelahiran 40 kasus (3,2\%) diantaranya adalah BBLR dan dari 40 kelahiran BBLR terdapat 4 orang bayi (10\%) yang meninggal.

Berat Bayi Lahir Rendah disebabkan oleh banyak faktor diantaranya faktor ibu, faktor bayi dan faktor plasenta. Faktor ibu yang berpengaruh terhadap kejadian BBLR diantaranya adalah umur, paritas, ras, infertilitas, riwayat kehamilan tidak baik, lahir abnormal, jarak kelahiran terlalu dekat, BBLR pada anak sebelumnya dan aktivitas ibu yang padat $^{3-6}$. Peneliti lain menambahkan salah satu penyebab BBLR adalah status pelayanan antenatal yang terdiri dari frekuensi dan kualitas pelayanan antenatal, tenaga kesehatan tempat periksa hamil, umur kandungan saat pertama kali pemeriksaan kehamilan) juga dapat beresiko untuk melahirkan $B B L R^{7}$. BBLR rentan infeksi sehingga terjadi sindrom gawat nafas, hipotermi, tidak stabil sirkulasi (oedema), hipoglikemi, hipokalsemia, hiperbilirubin ${ }^{8}$.

Penelitian ini bertujuan untuk mengetahui faktor-faktor yang berhubungan dengan kejadian Berat Badan Lahir Rendah (BBLR) di wilayah kerja Puskesmas Jawilan dan Petir Kabupaten Serang tahun 2019.

\section{METODE}

Penelitian ini menggunakan desain kasus kontrol untuk mengetahui faktor-faktor yang berhubungan dengan kejadian BBLR pada ibu yang melahirkan pada periode Januari sampai Desember tahun 2018 di wilayah kerja Puskesmas Jawilan dan Petir. Penelitian dilakukan pada bulan Maret sampai Juni 2019 dengan sampel sebanyak 142 orang yang terdiri dari sampel kasus sebanyak 71 orang dan sampel 
kontrol sebanyak 71 orang. Sampel kasus pada penelitian ini adalah ibu-ibu yang melahirkan bayi dengan berat lahir kurang dari $2500 \mathrm{mg}(2,5 \mathrm{~kg})$ dan sampel kontrol yaitu ibu yang melahirkan bayi dengan berat badan normal di puskesmas Jawilan dan Petir. Sampel dalam penelitian ini adalah total populasi. Pengumpulan data penelitian menggunakan data primer dengan melakukan pengukuran LILA, Frekuensi ANC, Riwayat Kehamilan, Preeklampsi dan Kejadian BBLR. Kriteria inklusi kelompok kasus penelitian adalah sebagai berikut:

1. Ibu yang tinggal di wilayah kerja puskesmas Jawilan dan Petir.

2. Ibu yang tercatat dalam buku register ibu di Puskesmas Jawilan dan Petir.

3. Ibu yang melahirkan bayi dengan BBLR tahun 2018 sesuai kriteria yang berlaku.

Kriteria inklusi kelompok kontrol adalah:

1. Ibu yang tinggal di wilayah kerja puskesmas Jawilan dan Petir Kabupaten Serang.

2. Ibu yang tercatat dalam buku register ibu di Puskesmas Jawilan dan Petir Kabupaten Serang.

3. Ibu yang melahirkan bayi dengan Berat Badan Lahir Normal tahun 2018 sesuai kriteria yang berlaku.

Instrumen yang digunakan dalam penelitian ini adalah pedoman KIA Kementerian Kesehatan. Pengolahan data yang dilakukan dalam penelitian ini adalah menggunakan aplikasi pengolah data kemudian dianalisis menggunakan analisis univariat dan bivariat. Analisis bivariat menggunakan uji Chisquare, dengan batas kemaknaan $\alpha(a / p h a)=5 \%$ dan Confidence Interval $(C l)=95 \%$.

\section{HASIL DAN PEMBAHASAN}

\section{Determinan BBLR}

Berdasarkan hasil penelitian diperoleh hasil sebagai berikut:

Tabel 1. Gambaran Distribusi Frekuensi Determinan BBLR

\begin{tabular}{lrc} 
No & \multicolumn{1}{c}{ Variabel } & n \\
1. $\quad$ Frekuensi ANC & & \\
$\quad$ K4 & 32 & 22,5 \\
$\quad$ Tidak K4 & 110 & 77,5 \\
2. Ukuran LILA & & \\
$\quad$ Gizi kurang baik & 48 & 33,8 \\
$\quad$ Gizi baik & 94 & 66,2 \\
3. Jarak kehamilan & & \\
$\quad$ Resiko & 59 & 41,5 \\
$\quad$ Tidak resiko & 83 & 58,5 \\
4. Preeklamsia & & \\
$\quad$ Preeklampsia & 26 & 18,3 \\
$\quad$ Tidak Preeklampsia & 116 & 81,7 \\
\hline$\quad$ Total & 142 & 100 \\
\hline
\end{tabular}

Sumber: Data primer, 2019

Ukuran LILA responden merupakan ukuran lingkar lengan bagian atas pada bagian trisep dan digunakan untuk perkiraan tebal lemak-bawahkulit. Ukuran LILA digunakan sebagai salah satu indikator keadaan gizi ibu hamil. Ukuran LILA pada penelitian dibedakan menjadi dua kategori yaitu gizi kurang apabila ukuran LILA responden $<23,5 \mathrm{~cm}$ dan kategori gizi baik jika ukuran LILA responden $\geq 23,5$ $\mathrm{cm}$. Jarak kehamilan pada penelitian ini dikategorikan menjadi dua yaitu jarak kehamilan beresiko apabila jarak antara kehamilan $<2$ tahun dan $>3$ tahun serta jarak kehamilan tidak beresiko apabila jarak antara kehamilan $\geq 2$ tahun dan $\leq 3$ tahun. 
Tabel 2. Faktor-faktor yang Berhubungan dengan Kejadian BBLR

\begin{tabular}{|c|c|c|c|c|c|c|}
\hline \multirow{2}{*}{ Variabel } & \multicolumn{4}{|c|}{ Kejadian BBLR } & \multirow{2}{*}{$\boldsymbol{P}$} & \multirow{2}{*}{ OR (Cl 95\%) } \\
\hline & & Kasus & Kontrol & Total & & \\
\hline \multicolumn{7}{|l|}{ Frekuensi ANC } \\
\hline \multirow[t]{2}{*}{ Tidak Baik } & $\mathrm{n}$ & 24 & 8 & 32 & & \\
\hline & $\%$ & 33,8 & 11,3 & 22,5 & 0,003 & $4,0(\mathrm{Cl} 95 \%=1,660-9,742)$ \\
\hline \multirow[t]{2}{*}{ Baik } & $\mathrm{n}$ & 47 & 63 & 110 & & \\
\hline & $\%$ & 66,2 & 88,7 & 77,5 & & \\
\hline \multirow{2}{*}{ Total } & $\mathrm{n}$ & 71 & 71 & 142 & & \\
\hline & $\%$ & 100 & 100 & 100 & & \\
\hline \multicolumn{7}{|l|}{ Ukuran LILA } \\
\hline \multirow[t]{2}{*}{ Gizi kurang baik } & $\mathrm{n}$ & 32 & 16 & 48 & & \\
\hline & $\%$ & 45,1 & 22,5 & 33,8 & 0,008 & $2,8(\mathrm{Cl} 95 \%=1,363-5,835)$ \\
\hline \multirow[t]{2}{*}{ Gizi baik } & $\mathrm{n}$ & 39 & 55 & 94 & & \\
\hline & $\%$ & 54,9 & 77,5 & 66,2 & & \\
\hline \multirow{2}{*}{ Total } & $\mathrm{n}$ & 71 & 71 & 71 & & \\
\hline & $\%$ & 100 & 100 & 100 & & \\
\hline \multicolumn{7}{|l|}{ Jarak kehamilan } \\
\hline \multirow[t]{2}{*}{ Resiko } & $\mathrm{n}$ & 35 & 24 & 59 & & \\
\hline & $\%$ & 49,3 & 33,8 & 41,5 & 0,089 & $1,9(\mathrm{Cl} 95 \%=0,968-3,747$ \\
\hline \multirow[t]{2}{*}{ Tidak resiko } & $\mathrm{n}$ & 36 & 47 & 83 & & \\
\hline & $\%$ & 50,7 & 66,2 & 58,5 & & \\
\hline \multirow{2}{*}{ Total } & $\mathrm{n}$ & 71 & 71 & 71 & & \\
\hline & $\%$ & 100 & 100 & 100 & & \\
\hline \multicolumn{7}{|l|}{ Preeklamsia } \\
\hline \multirow[t]{2}{*}{ Preeklamsia } & $\mathrm{n}$ & 17 & 9 & 26 & & \\
\hline & $\%$ & 23,9 & 12,7 & 18,3 & 0,129 & $2,1(\mathrm{Cl} 95 \%=0,894-5,263$ \\
\hline \multirow[t]{2}{*}{ Tidak Preeklampsia } & $\mathrm{n}$ & 54 & 62 & 116 & & \\
\hline & $\%$ & 76,1 & 87,3 & 81,7 & & \\
\hline \multirow{2}{*}{ Total } & $\mathrm{n}$ & 71 & 71 & 71 & & \\
\hline & $\%$ & 100 & 100 & 100 & & \\
\hline
\end{tabular}

Sumber: data primer, 2019

\section{PEMBAHASAN}

Berat Badan Lahir Rendah (BBLR) didefinisikan sebagai berat bayi yang lahir dengan berat kurang dari 2.500 gram. Berdasarkan beratnya, bayi BBLR dapat dikategorikan menjadi Bayi Berat Lahir Rendah (BBLR) dengan berat lahir 1.500-2.500 gram, Bayi Berat Lahir Sangat Rendah (BBLSR) apabila berat lahir 1.000-1.500 gram serta Bayi Berat Lahir Ekstrim Rendah (BBLER) apabila berat lahir kurang dari 1.000 gram $^{5}$. Faktor resiko kejadian BBLR pada penelitian ini diketahui bahwa jarak kehamilan tidak beresiko lebih banyak persentasenya dibanding jarak kehamilan beresiko, responden yang mempunyai frekuensi ANC baik juga menunjukkan persentase yang lebih banyak, status gizi ibu hamil yang diukur berdasarkan ukuran LILA juga lebih banyak pada kelompok yang status gizinya baik. Hasil penelitian ini sejalan dengan penelitian Mahayana, Chundrayetti dan Yulistini (2015) yang menyebutkan bahwa jarak kelahiran dan status gizi ibu yang tidak beresiko lebih banyak jumlah presentasinya dibanding dengan kelompok responden dengan jarak kelahiran rapat dan status gizi ibu yang kurang baik ${ }^{9}$.

\section{Frekuensi ANC}

Frekuensi ANC di Wilayah Kerja Puskesmas Jawilan dan Petir Kabupaten Serang menunjukkan bahwa dari 142 responden terdapat 32 responden (22,5\%) dengan frekuensi ANC tidak baik. Hal ini menggambarkan sebagian besar frekuensi ANC responden baik, namun masih ada responden dengan frekuensi ANC tidak baik. Sebanyak $88,0 \%$ responden memeriksakan kehamilan pada usia kehamilan 0-3 bulan, 87,3\% memeriksakan 
kehamilan pada usia kehamilan 4-6 bulan dan $87,3 \%$ pada usia kehamilan 7 bulan sampai dengan melahirkan yang dilakukan sebanyak $\geq 2$ kali. Pada kelompok kasus, responden dengan ANC tidak baik $33,8 \%$ lebih banyak dibanding responden kontrol sebanyak 11,3\%. Hasil penelitian menunjukkan ada hubungan yang signifikan antara frekuensi ANC dengan kejadian BBLR, dan merupakan faktor resiko terhadap kejadian BBLR. Penelitian ini sejalan dengan hasil penelitian sebelumnya yang dilakukan oleh Marlenywati, dkk., (2015) yang menunjukkan bahwa ibu dengan ANC kurang 4 kali melahirkan BBLR 12 (29,3\%), lebih besar dari pada ibu dengan ANC lebih 4 kali $^{10,11}$. Penelitian ini juga sejalan dengan penelitian Samir Husein yang menyebutkan kuantitas pelayanan antenatal dan kualitas pelayanan antenatal berpengaruh terhadap kejadian BBLR. ${ }^{12}$

Frekuensi ANC adalah jumlah kunjungan responden sewaktu hamil kepada petugas kesehatan yang kompeten untuk melakukan pemeriksaan kehamilan selama hamil. Berdasarkan Peraturan Menteri Kesehatan (PMK) Nomor 4 tahun 2019 tentang Standar Teknis Pelayanan Dasar Pada Standar Pelayanan Minimal Bidang Kesehatan, pemeriksaan kehamilan paling sedikit dilakukan 4 kali antara lain 3 bulan pertama minimal 1 kali, tiga bulan kedua minimal 1 kali dan tiga bulan ketiga minimal 2 kali. Pemeriksaan kehamilan sangat bermanfaat bagi ibu hamil dan janin. Pada ibu hamil pemeriksaan kehamilan dapat mengurangi komplikasi kehamilan, mengobati komplikasi secara dini yang akan mempengaruhi kehamilan, selain itu juga untuk meningkatkan kesehatan fisik dan psikis ibu dalam menghadapi persalinan bahkan dalam persiapan kesehatan ibu untuk persalinan dan memberikan ASI. Sedangkan bagi janin yaitu untuk memelihara kesehatan janin selama dalam kandungan dan mengurangi risiko premature, berat badan kurang ketika lahir atau bayi meninggal.

Tujuan dari pemeriksaan antenatal care menurut usia kehamilan (trimester):

\section{Trimester pertama (0-3 bulan)}

Pemeriksaan yang dilakukan untuk mengetahui risiko bahaya jiwa dan juga mencegah terjadinya anemia. Sehingga kondisi ibu hamil mendukung melanjutkan kehamilan di trimester selanjutnya.

\section{Trimester kedua}

Informasi yang didapat dari pemeriksaan antenatal care adalah unuk memberikan tingkat kewaspadaan ibu terhadap beberapa penyakit kehamilan yang sering kali terjadi. Beberapa diantaranya adalah gejala preeklampsia, tekanan darah tinggi atau pembengkakan.

\section{Trimester Ketiga}

Ibu hamil dapat diperiksa untuk mengetahui kondisi ibu dan juga tumbuh kembang janin mempersiapkan persalinan. Kondisi mental ibu hamil sangat berperan penting untuk membantu melancarkan proses persalinan.

Ibu hamil perlu melakukan pemeriksaan kehamilan (Antenatal Care) secara teratur. Dengan melakukan kunjungan $A N C$ secara teratur penyebab BBLR bisa diketahui lebih awal, misalnya anemia yang diketahui saat pemeriksaan kehamilan, petugas kesehatan dapat memberikan pendidikan kesehatan tentang cara meningkatkan kadar $\mathrm{Hb}$ atau asupan nutrisi yang baik selama hamil ${ }^{14}$. Pada kegiatan pemeriksaan kehamilan akan dilakukan pemeriksaan pada kesehatan ibu dan kandungan sehingga mampu mengurangi komplikasi kehamilan yang berpontensi untuk melahirkan bayi BBLR dan gangguan kehamilan lainnya. Ibu hamil pada saat ANC dilakukan pemeriksaan kondisi fisik ibu yang meliputi berat badan, tinggi badan, tekanan darah, LILA, pemeriksaan janin (letak janin, perkiraan berat janin), serta pemeriksaan laboratorium yang disesuaikan dengan perkembangan kehamilan. Atas dasar inilah sehingga frekuensi ANC merupakan salah satu faktor yang berhubungan dengan kejadian BBLR.

\section{Ukuran LILA Ibu Hamil dan BBLR}

Pertumbuhan janin dalam kandungan dapat dipengaruhi oleh status gizi ibu pada waktu pembuahan. Salah satu cara untuk menentukan status gizi ibu hamil adalah dengan cara mengukur antropometri, yaitu dengan mengukur lingkar lengan atas (LILA) dan kenaikan berat badan ibu hamil. Ukuran LILA yang sesuai menunjukkan status gizi ibu hamil yang baik.

Ukuran LILA adalah ukuran lingkar lengan bagian atas pada bagian trisep, LILA digunakan untuk 
perkiraan tebal lemak-bawah-kulit. Ambang batas LILA $<23,5 \mathrm{~cm}$ atau dibagian pita merah menandakan gizi kurang dan $\geq 23,5 \mathrm{~cm}$ menandakan gizi baik. LILA <23,5 termasuk kelompok rentan kurang gizi $^{14}$. LILA menggambarkan keadaan konsumsi makanan terutama konsumsi energi dan protein dalam jangka panjang oleh ibu hamil, ibu hamil yang memiliki tingkat kecukupan protein yang kurang (53\%) memiliki prevalensi KEK yang tidak berbeda dengan kecukupan protein yang baiksehingga dapat berimplikasi pada bayi yang sedang dikandung oleh ibu hamil ${ }^{13}$

Ibu hamil dengan Lingkar Lengan Atas $<23,5$ $\mathrm{cm}$ memiliki risiko Kurang Energi Kronis (KEK). Kurang Energi Kronis (KEK) pada ibu hamil dapat menyebabkan ukuran plasenta menjadi lebih kecil sehingga transfer oksigen dan nutrien ke janin jadi berkurang, sehingga hal ini akan berdampak pada BBLR. Hasil penelitian menunjukkan terdapat 33,8\% responden dengan ukuran LILA $<23,5 \mathrm{~cm}$ atau gizi kurang dan $66,2 \%$ responden dengan ukuran LILA $\geq 23,5 \mathrm{~cm}$ atau gizi baik. Hal ini menggambarkan bahwa sebagian besar ukuran LILA responden termasuk dalam kategori gizi baik. Hasil penelitian juga menunjukkan responden dengan gizi kurang pada kelompok kasus lebih besar $(45,1 \%)$ dibanding responden kontrol (22,5\%). Hasil analisis penelitian menunjukkan ada hubungan yang signifikan antara ukuran LILA dengan kejadian BBLR. Hasil penelitian ini sesuai dengan hasil penelitian yang dilakukan Marlenywati (2015) yang menunjukkan ada hubungan antara ukuran LILA dengan kejadian BBLR dimana proporsi BBLR lebih banyak terjadi pada ibu yang status gizi risiko (LILA kurang $23,5 \mathrm{~cm})^{11}$. Penelitian ini juga sejalan dengan hasil penelitian sebelumnya yang dilakukan oleh Fajriana, Buanasita (2018) yang menunjukkan bahwa pada kelompok kasus, 41\% ibu tergolong KEK (LILA kurang $23,5 \mathrm{~cm}$ ), sedangkan pada kelompok kontrol persentasenya sebesar $9,1 \%{ }^{16}$.

Ibu hamil perlu mendapatkan pendidikan kesehatan tentang pentingnya gizi selama kehamilan untuk mencegah risiko KEK. Apabila status gizi yang ditunjukkan dengan ukuran LILA $>23,5 \mathrm{~cm}$ belum tercapai sebaiknya kehamilan ditunda dulu agar tidak melahirkan bayi BBLR dan risiko lainnya. Ibu hamil yang sudah KEK disarankan harus mau meningkatkan asupan gizinya dengan makanan yang tinggi kalori dan tinggi protein. Oleh karena itu, sikap ibu hamil terhadap makanan yang bergizi dan pantang makan harus ditingkatkan dan dimotivasi agar ibu hamil mempunyai sikap dan perilaku makan yang baik dan sehat. Hal ini sesuai dengan hasil penelitian sebelumnya yang menyebutkan bahwa sikap ibu hamil terhadap makanan dan pantang makanan berhubungan secara signifikan terhadap kejadian $\mathrm{KEK}^{14}$.

\section{Jarak Kehamilan dan BBLR}

World Health Organization (WHO) dan Badan Koordinasi Keluarga Berencana Nasional (BKKBN) menyatakan bahwa jarak antar kehamilan sebaiknya 2 hingga 3 tahun. Jika kurang dari dua tahun, maka bisa berdampak buruk bagi kesehatan ibu maupun janin. Menurut Indrasari, jarak kehamilan beresiko (jarak kehamilan kurang dari 2 tahun) dapat meningkatkan risiko berat bayi lahir rendah ${ }^{18}$. Wanita yang hamil dengan jarak kehamilan sebelumnya $<2$ tahun cenderung akan melahirkan bayi BBLR. Ibu ini juga berisiko menderita anemia. Kehamilan yang berulang dengan waktu singkat dapat menyebabkan cadangan zat besi ibu terkuras untuk keperluan janin yang dikandungnya sehingga berpotensi tinggi menyebabkan berat bayi lahir rendah ${ }^{20}$. Jarak kehamilan merupakan risiko kejadian berat badan lahir rendah. Ibu yang memiliki jarak kehamilan $<2$ tahun berisiko 3,2 kali lebih besar untuk melahirkan berat badan lahir rendah dibandingkan dengan ibu yang memiliki jarak kehamilan $\geq 2$ tahun ${ }^{16}$.

Berdasarkan hasil penelitian diketahui bahwa terdapat 59 responden (41,5\%) dengan jarak kehamilan resiko dan 83 responden $(58,5 \%)$ tidak beresiko. Responden dengan jarak kehamilan $>3$ tahun sebanyak $38 \%$, 3,5\% responden dengan jarak kehamilan $<24$ bulan, sebanyak $37,3 \%$ responden yang mempunyai anak tunggal dan $62,7 \%$ responden multipara/anak kedua atau lebih. Pada kelompok kasus, responden dengan jarak kehamilan resiko sebanyak 49,3\% lebih banyak dibanding responden kontrol yaitu sebanyak $33,8 \%$. Penelitian ini sejalan dengan hasil penelitian sebelumnya yang menunjukkan pada responden kasus angka kejadian BBLR lebih tinggi dibandingkan pada kelompok kontrol ${ }^{18,21}$. Hasil analisis menunjukkan 
tidak ada hubungan yang signifikan antara jarak kehamilan dengan kejadian BBLR. Hasil penelitian ini berbeda dengan hasil penelitian yang dilakukan Marlenywati dkk, yang menunjukkan hubungan antara jarak kehamilan dengan BBLR. Hasil penelitian Marlenywati dkk, menyebutkan bahwa proporsi ibu dengan jarak kehamilan $<2$ tahun melahirkan BBLR 3 kali lebih besar daripada ibu dengan jarak kehamilan $\geq 2$ tahun dengan OR 3,0 (Cl $95 \% ; 1,17-7,83)^{11}$. Meskipun tidak sejalan dengan penelitian sebelumnya, namun penelitian ini sejalan dengan penelitian Jayanti, Dharmawan, Aruben yang menyebutkan bahwa tidak terdapat hubungan antara jarak kehamilan dengan kejadian BBLR, jarak kehamilan bukan merupakan faktor resiko BBLR OR $2,09$ ( $\mathrm{Cl} 95 \% ; 0,84-5,23)$ ). Kelompok responden dengan jarak kehamilan tidak beresiko mempunyai proporsi untuk melahirkan bayi dengan berat badan normal lebih banyak dibandingkan pada kelompok beresiko ${ }^{18}$.

Seorang ibu memerlukan waktu 2 sampai 3 tahun antara kehamilan yang satu dengan jarak kehamilan berikutnya agar pulih secara fisiologis dalam persalinan sebelumnya dan mempersiapkan diri untuk kehamilan berikutnya. Semakin kecil jarak antara kedua kelahiran, semakin besar risiko untuk melahirkan BBLR. Kejadian tersebut disebabkan oleh komplikasi perdarahan waktu hamil dan melahirkan, partus prematur dan anemia berat ${ }^{21,23}$.

\section{Preeklampsia dan BBLR}

Hasil penelitian menunjukkan tidak ada hubungan yang signifikan antara preeklampsia dengan kejadian BBLR. Responden dengan tekanan darah saat hamil $\geq 140 / 90 \mathrm{mmHg}$ sebanyak 90,1\%, responden dengan kadar protein dalam urin positif sebanyak $8,5 \%$. Pada tabel silang menunjukkan bahwa responden kasus dengan preeklampsia sebanyak $23,9 \%$ lebih banyak dibanding responden kontrol yaitu sebanyak $12,7 \%$. Responden dengan preeklampsia sebanyak 26 penderita sebagian besar adalah responden kasus atau yang mengalami BBLR yaitu $23,9 \%$ dan responden kontrol sebanyak $12,7 \%$. Hasil penelitian ini sesuai dengan hasil penelitian yang dilakukan Lisnawati, Humairah, Maineny (2019) yang menunjukkan tidak ada hubungan antara hipertensi dalam kehamilan (Preeklampsia) dengan kejadian $\mathrm{BBLR}^{23}$. Hasil penelitian tidak sejalan dengan penelitian Nurliawati, Mallisa yang menyebutkan bahwa ada hubungan yang signifikan antara riwayat kehamilan ibu dengan Preeklampsi Berat (PEB) dengan BBLR. Ibu yang mempunyai riwayat kehamilan dengan preeklampsi berat lebih banyak (55\%) yang melahirkan bayi dengan BBLR. Terdapat hubungan yang bermakna secara statistik antara preeklampsia dengan kejadian BBLR dan Preeklampsia merupakan faktor risiko lebih besar yang menyebabkan BBLR ${ }^{24,25}$.

Preeklampsia sebagai suatu syndrome spesifik pada kehamilan berupa berkurangnya perfusi plasenta akibat vasospasme dan aktivasi endotel yang akhirnya dapat mempengaruhi seluruh sistem organ, ditandai dengan hipertensi dan proteinuria pada pertengahan akhir kehamilan atau di atas 20 minggu kehamilan ${ }^{19}$. Vasospasme menyebabkan terjadinya konstriksi vaskular pada berbagai organ termasuk plasenta. Resistensi aliran darah karena konstriksi vaskular akan menyebabkan hipertensi arterial pada plasenta. Menurunnya aliran darah ke plasenta menyebabkan gangguan fungsi plasenta sehingga terjadi gangguan pertumbuhan janin $^{19}$. Dengan menurunnya aliran darah ke plasenta mengakibatkan gangguan fungsi plasenta, sedangkan fungsi plasenta adalah untuk menyalurkan asupan oksigen dan asupan gizi dari ibu ke janin. Jika asupan gizi dan asupan oksigen bagi janin terganggu maka dapat mengakibatkan gangguan pertumbuhan janin sehingga berat badan janin yang dilahirkan rendah. Preeklampsia dalam kehamilan berisiko menyebabkan BBLR pada responden 10 kali lebih besar dibandingkan pada responden yang tidak preeklampsia (OR=10,1 (95\% Cl:4,231-24,196) ${ }^{19}$.

Menurut Manuaba (2007) ${ }^{27}$, BBLR dapat terjadi karena adanya hambatan pertumbuhan saat dalam kandungan. Retardasi pertumbuhan intrauterin berhubungan dengan keadaan yang mengganggu sirkulasi dan efisiensi plasenta dengan pertumbuhan dan perkembangan janin atau dengan keadaan umum dan gizi ibu. Keadaan ini mengakibatkan kurangnya oksigen dan nutrisi secara kronik dalam waktu yang lama untuk pertumbuhan dan perkembangan janin. 


\section{KESIMPULAN DAN SARAN}

\section{Kesimpulan}

Frekuensi ANC dan ukuran LILA merupakan faktor yang berhubungan secara dengan kejadian BBLR. Pemeriksaan kehamilan secara teratur dapat mencegah resiko terjadinya BBLR sejak dini. Ukuran LILA menjadi salah satu indikator gizi pada ibu hamil. Dengan gizi yang baik maka pertumbuhan janin dalam kandungan juga akan semakin baik, sehingga dapat mencegah terjadinya BBLR.

\section{Saran}

Perlunya Puskesmas menyediakan makanan tambahan bagi ibu/calon ibu khususnya yang beresiko terjadi BBLR melalui berbagai sumber daya.

\section{DAFTAR PUSTAKA}

1. BKKBN. SDKI 2017 [Internet]. Survei Demografi dan Kesehatan Indonesia. 2017. Available from: https:// www.un.org/sustainabledevelopment/wp-content/ uploads/2015/08/Factsheet_Summit.pdf

2. Kemenkes RI. Hasil Utama Riset Kesehatan Dasar Tahun 2018. Kementrian Kesehatan Republik Indonesia. 2018.

3. Kementerian Kesehatan Republik Indonesia. Kementerian Kesehatan Republik Indonesia. Kementerian Kesehatan RI. 2018.

4. England. C. The Healthy Low Birth Weight Baby. In: Myles Texbook For Midwives. Churchill Livingstone Elsevier; 2015.

5. Sudarti. Asuhan Kebidanan Neonatus Risiko Tinggi dan Kegawatan. Yogyakarta; 2013.

6. Proverawati, Ismawati C. Berat Badan Lahir Rendah (BBLR). Yogyakarta; 2010.

7. Kumalasary D. Faktor-Faktor Yang Mempengaruhi Kejadian Berat Bayi Lahir Rendah ( BBLR ) DI Puskesmas Wilayah Kecamatan Harjamukti Kota Cirebon Tahun 2016. J Ris Kebidanan Indones. 2018;2(1):21-7.

8. Little GA, Keenan WJ, Niermeyer $S$, Singhal H, Lawn JE. Neonatal Nursing and Helping Babies Breate: An Effective Intervention To Decrease Global Neonatal Mortality. In: Newborn and Infant Nursing Review. 2011.

9. Sukarni I, Sudarti. Patologi Kehamilan, persalinan, nifas, dan neonatus resiko tinggi. Yogyakarta: Nuha Medika; 2014.

10. Mahayana SAS, Chundrayetti E, Yulistini. Artikel Penelitian Faktor Risiko yang Berpengaruh terhadap Kejadian Berat. Jurnal.fk.unand.ac.id. 2015;4(3):664-73.

11. Fatimah N, Utama BI, Sastri S. Hubungan Antenatal Care Dengan Kejadian Bayi Berat Lahir Rendah pada Ibu Aterm di RSUP Dr. M . Djamil Padang. J Kesehat Andalas. 2015;6(3):615-20.

12. Marlenywati, Hariyadi D, Ichtiyati F. Faktor-faktor yang mempengaruhi kejadian BBLR di RSUD $\mathrm{dr}$. Soedarso Pontianak. Vokasi Kesehatan, 1(5), 154-160.-faktor yang mempengaruhi kejadian BBLR di RSUD dr. Soedarso Pontianak. Vokasi Kesehat. 2015;1(5):154-60.

13. S Husein -. Pengaruh Antenatal care terhadap kejadian Berat Bayi Lahir Rendah (BBLR). JournalUnairAcld [Internet]. 2014;3(2):160-7. Available from: http://journal.unair.ac.id/downloadfullpapers-biometrik7bcfc1f1bafull.pdf

14. Tazkiah M, Wahyuni CU, Martini S. Determinan Epidemologi Kejadian BBLR pada Daerah Endemis Malaria di Kabupaten Banjar Provinsi Kalimantan Selatan. J Berk Epidemologi. 2013;1(2):266-76.

15. Ariyani DE, Achadi EL, Irawati A. Validitas Lingkar Lengan Atas Mendeteksi Risiko Kekurangan Energi Kronis pada Wanita Indonesia. Kesmas Natl Public Heal J. 2012;7(2):83.

16. Azizah A, Adriani M. Tingkat Kecukupan Energi Protein Pada Ibu Hamil Trimester Pertama Dan Kejadian Kekurangan Energi Kronis. Media Gizi Indones. 2018;12(1):21.

17. Fajriana A, Buanasita A. Faktor Risiko Yang Berhubungan Dengan Kejadian Bayi Berat Lahir Rendah Di Kecamatan Semampir Surabaya. Media Gizi Indones. 2018;13(1):71.

18. Amirudin Z, Wijanarko B, K MI. Kurang Energi Kronis Pada Ibu Hamil di Kota Pekalongan. J Promosi Kesehat Indones. 2011;6(2):169-76.

19. Indrasari N. Faktor Resiko Pada Kejadian Berat Badan Lahir Rendah (Bblr). J Keperawatan. 2012;8(2):11423.

20. Syifaurrahmah $\mathrm{M}$, Yusrawati $\mathrm{Y}$, Edward Z. Hubungan Anemia dengan Kejadian Bayi Berat Lahir Rendah pada Kehamilan Aterm di RSUD Achmad Darwis Suliki. J Kesehat Andalas. 2016;5(2):470-4.

21. Obai G, Odongo P, Wanyama R. Prevalence of anaemia and associated risk factors among pregnant women attending antenatal care in Gulu and Hoima Regional Hospitals in Uganda: A cross sectional study. BMC Pregnancy Childbirth [Internet]. 2016;16(1):17. Available from: http://dx.doi.org/10.1186/ s12884-016-0865-4

22. Nur R, Adhar A, Redita N. Analisis Faktor Risiko Kejadian Berat Badan Lahir Rendah di Rumah Sakit Umum Anutapura Palu. J Prev. 2016;1(Maret):1-64. 
23. Monita F, Suhaimi D, Ernalia Y. Hubungan usia, jarak kelahiran dan kadar hemoglobin ibu hamil dengan kejadian berat bayi lahir rendah di rsud arifin achmad provinsi riau. Jom FK. 2016;3(1):1-17.

24. Fatima Anggi Jayanti, Yudhy Dharmawan RA. FAKTOR-FAKTOR YANG BERHUBUNGAN DENGAN KEJADIAN BERAT BADAN LAHIR RENDAH DI WILAYAH KERJA PUSKESMAS BANGETAYU KOTA SEMARANG TAHUN 2016. J Kesehat Masy. 2012;5(4):812-22.

25. Lisnawati, Humairah NN, Maineny A. Preeclamsia and Low Birth Weight ( LBW ) In Anutapura Palu General Hospital Poltekkes Kemenkes Palu. Poltekita J Ilmu Kesehat. 2019;13(1):42-7.
26. Nurliawati E. Hubungan Antara Preeklamsia dengan prematuritas. J Kesehat Bakti Tunas Husada. 2014;12(1):22-7.

27. Mallisa B, Towidjojo VD. Hubungan Antara Preeklampsia Dengan Kejadian Bayi Berat Badan Lahir Rendah (Bblr) Di Rsud Undata Palu. Med TADULAKO, J Ilm Kedokt [Internet]. 2014;1(3):1-7. Available from: http://jurnal.untad.ac.id/jurnal/ index.php/MedikaTadulako/article/view/7934/6273

28. Cunningham. Obstetri Williams. Jakarta: EGC; 2013.

29. Manuaba I. Pengantar Kuliah Obstetri. Jakarta: EGC; 2007. 